\title{
Craftsmanship and the cultural / political identity of the Cypriote kingdoms. The case of Idalion and Tamassos
}

Karin Nys, Matthias Recke

\section{Résumé}

Dans cette contribution, nous examinons les rapports entre les entités politiques chypriotes de l'Âge du Fer et leur production artistique. Les données disponibles provenant d'Idalion et de Tamassos nous permettent de chercher si les styles régionaux étaient dictés et contrôlés par les élites du pouvoir. Nous examinons aussi ce que cela implique sur les interactions entre ces deux royaumes à l'Âge du Fer.

\section{Citer ce document / Cite this document :}

Nys Karin, Recke Matthias. Craftsmanship and the cultural / political identity of the Cypriote kingdoms. The case of Idalion and Tamassos. In: Cahiers du Centre d'Etudes Chypriotes. Volume 34, 2004. pp. 211-222;

doi : $10.3406 /$ cchyp.2004.1465

http://www.persee.fr/doc/cchyp_0761-8271_2004_num_34_1_1465 
Cahier du Centre d'Études

Chypriotes 34, 2004

\title{
CRAFTSMANSHIP AND THE CULTURAL/POLITICAL IDENTITY OF THE CYPRIOTE KINGDOMS The Case of Idalion and Tamassos 1
}

\author{
Karin NYS and Mathias RECKE
}

\begin{abstract}
Résumé. Dans cette contribution, nous examinons les rapports entre les entités politiques chypriotes de l'Âge du Fer et leur production artistique. Les données disponibles provenant d'Idalion et de Tamassos nous permettent de chercher si les styles régionaux étaient dictés et contrôlés par les élites du pouvoir. Nous examinons aussi ce que cela implique sur les interactions entre ces deux royaumes à l'Âge du Fer.
\end{abstract}

Epigraphic documents attest that the two neighbouring, inland sites, Idalion and Tamassos, were kingdoms during the Cypro-Archaic period, and that - within an interval of nearly a century - they were both incorporated by the kingdom of Kition during the Cypro-Classical period, thereby losing their independent status. The geographical position of Idalion and Tamassos must have been both a blcssing and a curse: while the two polities could thrive on the exploitation of the nearby copper mines, they also had to withstand the economic interest of other Cypriote polities in these natural resources. In addition, we may assume that, because of their inland position, Idalion and Tamassos were forced to seek economic collaboration with polities that had direct access to the sea for the export and exchange of commodities beyond the island. We may further expect that the control of ore-mining and forestry activities must have been a potential source of territorial strife between the two inland kingdoms. Therefore, the geo-economic reality likely induced Idalion and Tamassos to a dualistic relationship of being both allies and competitors.

The key questions for today's historical investigators is how this complex peerpolity interaction was reflected in the material culture and to what extent this interaction can be extracted from the preserved archaeological data. Case studies in areas outside Cyprus have shown that by examining different categories of material culture we may

1. We wish to thank the organizers of the colloquium, particularly Dr. Sabine Fourrier, for kindly accepting our contribution. We also would like to thank Prof. dr. Nancy Serwint for editorial assistance. 
infer the dynamics of inter-site relations and gain insights into the socio-economic and political organisation of those sites. ${ }^{2}$ The display of certain types of artefacts is central to the formation and consolidation of hierarchies on both an intra- and inter-polity level. Furthermore, stylistic variations within particular media may reflect specific groups wishing to create a distinct profile for themselves. ${ }^{3}$ A case in point is the reign of Amenophis IV/Akhenaten whose religious reformation went hand in hand with a remarkable change in the arts. As high priest of the god Ptah, Amenophis IV/Akhenaten was also called "Greatest of Craftsmen," which implies that he monitored the design of all types of artwork. The assumption that he was, indeed, the main instigator of the drastic change in style is corroborated by inscriptions of his chief architect, Ma'nakhtuf, and chief sculptor, Bek, in which they describe themselves as "the apprentice whom his majesty, himself, had taught."4

Within the realm of Cypriote studies, Rupp was able to disclose a vertical characterisation of the Cypriote Iron Age society. By analysing the types of artefacts in Cypro-Geometric and Cypro-Archaic burial assemblages, he distinguished three different social strata. He further observed that from CG III onwards Cypriote society was marked by a clear tripartite division linked to a specific spatial distribution of the three social strata: on top a small, ruling class ("governing elite"), residing nearly exclusively in the urban centres; a slightly larger middle stratum ("non-governing elite"), which lived in both the urban centres and in towns in the hinterland; and, finally, the lowest but biggest social stratum ("commoners"), which was present in the former two types of settlements and in small villages. Rupp argued that the latter pattern reflects the emergence in CG III of territorial kingdoms each with a distinct stratified society. ${ }^{5}$ Next to this vertical characterisation, we may also expect to detect in the material culture of the Cypriote Iron Age a horizontal characterisation of its society, namely indications that the upper strata within each polity wished to convey a characteristic cultural image of themselves, which would clearly distinguish them from their peers in other polities and which would token their socio-economic and political power.

This would imply that concurrently with the rise of the Iron Age kingdoms, regional styles would emerge in each of them. Regional styles have, indeed, been detected in several categories of Cypriote Iron Age artefacts, particularly in classes of decorated pottery, ${ }^{6}$ terracotta $^{7}$ and limestone ${ }^{8}$ sculpture, and glyptics. ${ }^{9}$ Furthermore, in the

2. E.g., Arafat, Morgan 1989 and Morgan, Whitelaw 1991 for Iron Age Greece and Nijboer 1997 for central Italy during the 8th to 6th centuries B.C.

3. Morgan 1991; Morgan, Whitelaw 1991.

4. Aldred 1988, 232-3, 259.

5. Rupp 1989.

6. In his seminal study of the material culture of the Cypriote Iron Age, Gjerstad already observed a regional distinction of two pottery groups emerging at the end of the CyproGeometric period and fully developing during the Cypro-Archaic period: the southern and eastern parts of the island seemingly favoured White Painted and Bichrome wares and a figurative decoration, while Black-on-Red and Bichrome Red wares and a geometric decoration were dominant in northern and western Cyprus (Gjerstad 1948, 461; Gjerstad 
framework of her study of the Cypro-Archaic terracottas and their function within the trading mechanisms of the eastern Mediterranean, Fourrier identified distinct terracotta productions, which she placed within the landscape of the Cypriote Iron Age kingdoms. ${ }^{10}$

So, seemingly, there does exist a correlation between a given polity and its artistic production. The question should be asked, however, as to what is the nature of this correlation? Were the regional styles, which we observe in the territories of the Cypriote Iron Age kingdoms, dictatcd and controlled by their respective governing elites in the same manner as Akhenaten had created the "Amarna style" in Egypt during the New Kingdom? Or in other words: were crafts used in the Cypriote Iron Age kingdoms to consciously convey a cultural and political identity? Before we can formulate answers to these questions, we must assess in which way the horizontal characterisation of the Cypriote Iron Age society would be expressed in its material culture. We may imagine that junctures of interaction between the upper strata of the polities would lead to an emphatic display of tokens of their political and socio-economic status. During occasional events involving direct face to face contacts, display could take the form of rich clothing and the presence of rich commodities in a luxurious setting. However, the elites were undoubtedly also seeking ways to overtly display their status on a more permanent level and, for this purpose, erecting medium-size and life-size effigies of themselves as votaries in the temene of sanctuaries would seem an obvious choice. Extra-urban sanctuaries would be particularly suitable to this end, as they could well have acted as border markers of the territories of the polities. ${ }^{11}$ In this way the ex-votos

$1960,105-7)$. In subsequent studies, other scholars isolated specific classes of decorated pottery in relation to their spatial and chronological production and distribution pattern (for pottery with painted decoration see Reyes 1994, 107-15 with further references; for pottery with plastic decoration see Vandenabeele 1998; Nys 2000; Nys forthcoming). These are, however, all studies based on macroscopic analyses. Mineralogical and chemical analyses would undoubtedly enhance our knowledge of the production, distribution and use of Cypriote pottery, but such studies are still rarely undertaken. To date, Bieber is the only one to have tested hypotheses about inter-site relations on the island through a neutron activation analysis of Cypriote pottery. Unfortunately, he used a limited sample size, which was not quite representative for the Cypriote Iron Age landscape, and, consequently, many questions remained unanswered. Nevertheless, Bieber's study represents a commendable first step (Bieber 1989; see also for critical remarks Jones, Catling 1986, 530-1, 612-3). Drawing up regional pottery sequences from stratified settlement contexts - like that proposed by Gaber for Idalion (Gaber 2000) - will certainly further elucidate the regional idiosyncrasies of Cypriote pottery.

7. E.g., Caubet 1992 (Idalion); Caubet, Yon 1989 (Kition); Winter 1991, Winter 1996 (Kourion); Yon, Caubet 1988 (Lapithos); Monloup 1984, Monloup 1994 (Salamis); Caubet 1991 (western Cyprus).

8. E.g., Gaber-Saletan 1986, Gaber 1989 (Idalion); Gaber-Saletan 1980, Caubet, Yon 1994 (Kition); Hermary 1996 (Kourion); Gaber-Saletan 1981 (Vouni); Yon 1974 (Salamis).

9. Reyes 1994, 115-21; Reyes 2001.

10. Fourrier 1999, 23-139.

11. Fourrier 2002, 140-1. 
in the temene - and particularly the sculptures - were emphatic expressions of a polity's authority on significant junctures in the landscape. It is noteworthy though, that pre-Hellenistic, Cypriote anthropomorphic sculptures never betray the features of individuals and that inscriptions never identify a statue with a particular donor. 12 Consequently, the donors' objective was not that so much to indicate their personal status but instead to emphasise their affiliation to the upper stratum in society. This would be embodied by the display of paraphernalia of their high status on the statues. ${ }^{13}$ The large size of the sculptures would represent another reference to the upper class, since the carving of such statues implied time-consuming labour and, thus, a costly investment that could only be made by well-to-do members of society. 14

From the above we may deduce that sculpture constitutes a good medium for further investigation of the possible conscious impact of the upper classes on the creation of regional styles. ${ }^{15}$ Wriedt Sørensen states that "If members of the royal families also functioned as priests and priestesses during the Archaic period it is even more likely that new phenomena such as large stone sculpture were monitored by them and used to emphazise their own importance." 16 Consequently, she argues for an intentional control over the carving by the governing classes, which could explain the subsequent emergence of regional sculptural styles. In the following sections, we propose to examine the validity of this assertion against the background of the available data on sculpture from Idalion and Tamassos. ${ }^{17}$

Large-scale terracotta sculpture was created on the island during the first half of the 7 th century B.C. ${ }^{18}$ In the latter half of the 7 th century B.C., large-scale statues were likewise executed in limestone. ${ }^{19}$ The sculptures of the Cypro-Archaic period unmistakably bear a Cypriote idiosyncratic stamp, although that stylistic characterization gradually devalues during the subsequent periods as Greek influence on

12. Senff $1993,69$.

13. E.g., Maier 1989; Senff 1993, 68-73; Brönner 1994, 51-2.

14. For the time-consuming labour of marble carving and the cost price of sculptures in the Greek world see Mark 1995, 29 and n. 31.

15. Other classes of material culture seem less suitable for this investigation. Textiles for example are no longer traceable in the archaeological data. For metal objects, Morgan has argued that these are more often the produce of itinerant metalworkers and that they are more likely to reflect external influences (Morgan 1991, 134; Morgan, Whitelaw 1991, 93). Regional styles would therefore be less apparent in metal artefacts - an assertion that is corroborated by the rather uniform style of metal objects of the Cypriote Iron Age (e.g., Matthäus 1985; Reyes 1992). In principle, decorated fine pottery could offer an alternative medium to sculpture, but to date we still lack sufficient pottery sequences from stratified contexts for each of the Cypriote polities.

16. Wriedt Sørensen 1994, 88.

17. We do not intend to present here an exhaustive study of all the sculpturcs of Idalion and Tamassos. Rather, the objective is to highlight patterns that can be discerned in terracotta and limestone productions from both polities.

18. Hermary 1991, 145-6; Karageorghis 1993, 6.

19. Gaber 1989, 401. 
Cypriote material culture becomes increasingly dominant. ${ }^{20}$ Therefore, it seems appropriate to concentrate in this study on Cypro-Archaic productions.

A regional style can best be identified in the facial characteristics of anthropomorphic statues. Typical Idalian terracotta sculpture shows a squarish face with a broad jaw, prominent cheek bones, a large nose, drop-shaped eyes that are frequently placed very near the nose, eyebrows that are often feathered, and a fairly small mouth with a thin upper lip. The female and beardless male representations have a prominent chin, which is often quite heavy and marked by vertical grooves on either side. ${ }^{21}$ Similar features can be noted on limestone sculpture from Idalion. ${ }^{22}$ Hermary conjectures that the creation of large-scale limestone sculpture was influenced by the older production of large-scale statues in terracotta. ${ }^{23}$ Since it has been suggested that carvers of Archaic and Classical Greek sculptures employed full-scale models of clay or plaster, ${ }^{24}$ it seems conceivable that Cypriote stone sculptors used large-scale terracottas as a model, which would go far in explaining the similarities in style between the two media. In spite of their small size, terracotta figurines from Idalion show the same idiosyncrasies of the large-scale sculpture. ${ }^{25}$ In sum, we observe recurrent characteristics in the sculptural production of Idalion, regardless the medium (terracotta or limestone) or the size (small, medium or life-size), and, consequently, a regional style can be identified for Idalion. Is this also true for Tamassos? Examining the whole of large-scale terracotta sculptures known to us, we note many examples that are akin to the "Idalion Style", i.e., they have the same facial characteristics as the local sculptures from Idalion. ${ }^{26}$ Other statues, however, show more affinities with terracotta productions from the northwestern part of the island, which are characterised by more delicate faces with almond-shaped eyes and full lips. ${ }^{27}$ Seemingly, there is no distinct style peculiar to Tamassos itself. A similar pattern

20. Gaber 1986, 20-5; Karageorghis 1991, 14.

21. E.g., Karageorghis 1993, 45, $\mathrm{n}^{\circ} 112$, pl. XXVIII:6; 45-6, nos $114-115$, pl. XXIX:2-

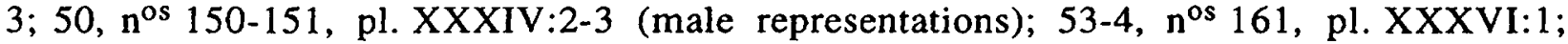
55-6, nos 167-168, pl. XXXVIII:4-5; 68-9, nos 235-238, pl. XLVII:3-5, XLVIII:1 (female representations).

22. E.g., Brehme et al. 2001, 132, $\mathrm{n}^{\circ} 139 ; 143-4, \mathrm{n}^{\circ} 154 ; 147-8, \mathrm{n}^{\circ} 158$. See also chart in Gaber-Saletan 1986, 25.

23. Hermary 1991, 146.

24. Boardman 1985, 14; Palagia 1987, 78-80.

25. E.g., Karageorghis 1999, 33-4, nos I(iv)86-90, pl. VIII:1-4; 147, n $^{\text {os }}$ IV(I) 1-3, fig. 37, pl. XXXVII:7. Fourrier $(1999,92)$ reckoned that $76.4 \%$ of all terracottas from Idalion were local productions; imports were mainly from Kition $(9.8 \%)$ and Salamis (7.3\%).

26. E.g., Karageorghis 1993, 47, $\mathrm{n}^{\circ} 131$, pl. XXXI:3; 50-1, $\mathrm{n}^{\circ} 152$, pl. XXXIV:5, 51, nos 154-155, pl. XXXV:1-2.

27. Compare, for example, three heads from Tamassos-Frangissa (Karageorghis 2003, 91 2 , $\mathrm{n}^{\text {os }} 140-142$ ) with three heads from Limniti (Brehme et al. 2001, 116-8, $\mathrm{n}^{\text {os }} 113-114$ and 116). 
emerges from the examination of Cypriote productions of small terracottas. ${ }^{28}$ Although the picture is less clear for the limestone sculpture, we can nevertheless also point to examples from Tamassos that are akin to the "Idalion Style." 29 Summarising, it appears that a distinct style developed at Idalion, but not at Tamassos and, in addition, that the majority of the sculpture from Tamassos can be placed within the "Idalion Style."

What can we infer from the above data on sculpture from Idalion and Tamassos regarding the degree of intentional control exercised by the upper strata of the two polities on the artistic production and, furthermore, what does this information imply about the peer-polity interaction between the Iron Age kingdoms? We propose to formulate answers to these questions by viewing the data within, alternatively, a positive and a negative response to the following thesis: regional styles are the result of a deliberate monitoring by the upper strata of the Cypriote Iron Age society that are wishing to convey a cultural and political identity.

If the thesis is valid, then we would expect the emergence of a distinct regional style in both polities. However, we have noticed that this only happened at Idalion and that Tamassos not only lacked its own regional style but also the majority of the sculptures fit within the "Idalion Style." If we also consider the observation that Idalion had its own coinage but that, to date, no coins have ever been attributed to Tamassos, we might infer that Tamassos was in fact a subordinate polity, governed by local elites, but economically secondary to Idalion. This inference was first suggested by Bieber ${ }^{30}$ and subsequently by Gaber. ${ }^{31}$ They substantiated this idea with the assumption that the Cypriote copper industry involved a two-phase process, whereby the primary smelting occurred nearby the mines in the territory of Tamassos, while Idalion was in charge of a secondary copper smelting in addition to the subsequent marketing of the metal to a harbour town like Kition. Other studies, however, have shown that during the Iron Age not only secondary smelting occurred within the territory of Tamassos ${ }^{32}$ but also that the metal industry was even present within its urban centre. ${ }^{33}$ Iacovou also conjectures that Tamassos was a subordinate polity, however, not to Idalion but to a kingdom in command of harbours. She advances Salamis as a likely candidate based upon the fact that there were no copper sources near Salamis and its agricultural resources alone could not explain the wealth and grandeur that this polity displayed during the Iron Age. ${ }^{34}$ Yet, we could equally consider Amathous - another kingdom with direct access to the

28. Compare a female figurine from Idalion (Karageorghis 1999, 33, $\mathrm{n}^{\circ} \mathrm{I}$ (iv)86, pl. VIII:1) with similar type of figurines from Tamassos (Karageorghis 1999, 35-7, $\mathrm{n}^{\text {os }}$ I(v)91-97, pl. VIII:5-8, IX:3). See also Fourrier 1999, 96-9, 131.

29. E.g., Pryce 1931, 26, $\mathrm{n}^{\circ} \mathrm{C} 30$, fig. $25 ; 30, \mathrm{n}^{\circ} \mathrm{C} 39$, fig. 33 .

30. However, Bieber's chemical pottery analyses could neither support nor refute this hypothesis (Bieber 1989, 368).

31. Gaber 1995, 32-3.

32. Given, Knapp et al. 2003, 219-23.

33. Buchholz, Untiedt 1996, 29.

34. Iacovou 2002, 79. 
sea - as the polity, that exercised economic control over Tamassos, since some classes within the material culture point to a close connection between Tamassos and Amathous. ${ }^{35}$ In addition, a road running between Tamassos and Amathous could have been in use as early as the Cypro-Archaic period, ${ }^{36}$ which is a further indication of welldeveloped economic contacts between both polities.

Let us now conceive that the above-formulated thesis is invalid. The observed "Idalion Style" would then not be the result of an intentional monitoring of the crafts by the ruling class at Idalion, but, conversely, would have been developed autonomously by the artisans that were active in the area. Artisans would not be subjected to the ruling class but would enjoy an independent status. Unfortunately, Cypriote craftsmen are hardly visible in the antique sources or the epigraphic data; of the few existing references ${ }^{37}$ only one inscription seems to predate c. 400 B.C., viz. the signature of the sculptor, Sikon of Cyprus, on the base of a limestone sculpture found at Naukratis. ${ }^{38}$ Pliny mentions another Cypriote sculptor: "Styppax of Cyprus is known for a single statue, his Man cooking tripe, which represented a domestic slave of the Olympian Pericles roasting inwards and puffing out his cheeks as he kindles the fire with breath"; ${ }^{39}$ based upon Pliny's description of the sculpture, Styppax was probably not active before the late Classical or even Hellenistic period. The Cypriote material culture equally provides limited information: we know of only one example of a craftsman at work, viz. a limestone figurine, datable to the late Cypro-Archaic period, from a tomb at Amathous showing a male potter throwing a vessel. 40

Can we induce more information about the status of Cypriote craftsmen by examining their peers in other cultures and times? Although the Greek literary sources transmit to us a profound disdain for banausic labour, the material culture of Archaic and Classical Greece conveys a totally different picture: craftsmen appear as a self-conscious class, asserting their status and identity by representing themselves at work or in settings that were associated with the upper stratum of society, i.e., the symposium and gymnasium. Social mobility was possible and for some individuals, it is known that they became very wealthy through their craft and could afford the dedication of life-size statues. ${ }^{41}$ In this framework, the style of a particular workshop could be associated with a particular client when the latter had privileged ties with the former, resulting in

35. E.g., the production of jugs with a zoomorphic head on the shoulder in the Tamassos area seems to have received its direct impetus from a similar production at Amathous (Nys forthcoming). The distribution pattern of the coinage in the Tamassos area also points to preferential contacts between the two polities (personal communication by Prof. H.-G. Buchholz).

36. Bekkcr-Nielsen 2001, 252.

37. Mitford 1971, 260, n. 1; Masson 1977; Mitford 1980.

38. Hogarth 1898-9, 32.

39. NH 34.81.

40. Pryce $1931,91, \mathrm{n}^{\circ} \mathrm{C} 225$, fig. 146.

41. Philipp 1990; Mark 1995; Tanner 1999. 
multiple orders at the same workshop. ${ }^{42}$ An entirely different picture emerges for Egypt during the New Kingdom, as contemporary documents attest that even freemen were "of the land of the Pharaoh," implying that they were dependent on the ruler owing him taxes and services. Even highly qualified artisans never had an independent status but belonged to higher authorities. ${ }^{43}$ In the Neo-Assyrian state, craftsmen could be attached to the ruler but the existence of self-employed craftsmen in the cities cannot be ruled out. ${ }^{44}$ From Mycenaean ${ }^{45}$ and Hittite ${ }^{46}$ documents we may infer that craftsmen - even those that were attached to the ruler - could be paid in land from which they had to support themselves and their families. The latter information is interesting in conjunction with the knowledge that the famous bronze tablet from Idalion attests that the medical doctor, Onasilos, and his brothers received land in gratitude for their services during a siege of Medes and Kitians. ${ }^{47}$ If craftsmen like sculptors and potters could likewise be remunerated in land, then we may assume that they would predominantly be active within the territory to which their land belonged. Consequently, a distinct style could become associated with a specific territory or polity.

We may further wonder to what extent craftsmen had free access to the raw material needed for their craft; if the resources were controlled by the polity, then craftsmen would be at least partly attached to the polity's ruling class. Here again the epigraphic and literary sources are quite mute. Only in one instance, the literary sources give evidence of polity control over the resources, viz. the Cypriote kings being in charge of forestry. ${ }^{48}$ Scholars generally assume that the Cypriote kings governed as absolute rulers and, therefore, were in control over all mineral resources. In fact, there are no data available to substantiate this conjecture. ${ }^{49}$ Some information may possibly be inferred by examining the situation in the Aegean world. In the framework of metallurgy at Mycenaean Pylos, Gillis argues convincingly that the palace was not involved in the redistribution of raw material, i.e., copper, but instead demanded part of the finished products in bronze. The Mycenaean smith was, therefore, "an independent craftsman, paying his taxes to the central authority in the form of metal objects and plying his specialized and demanding craft in his village." 50 Moving to Archaic and Classical Greece, we learn from literary and epigraphic sources that the exploitation of stone quarries was predominantly a private matter; only in Roman times did the quarries fall

42. Viviers 1995, 221.

43. Eyre 1987, 211.

44. Postgate 1987, 267.

45. Bech Gregersen 1997.

46. Beal 1988.

47. Masson 1983, 235-44, 414-5 n 217.

48. Theophrastus, $H P$ 5.8.1. For forestry and woodworking in the eastern Mediterranean during antiquity, see Buchholz 2004.

49. Given, Knapp et al. 2003, 273.

50. Gillis 1997, 511-3. 
under the control of the emperor. ${ }^{51}$ It would seem that polity control over resources is less obvious than one may expect at first and it is far from certain whether the rulers of Cypriote Iron Age polities had absolute control over resources such as quarries. We might conceive that Cypriote craftsmen had free access to the raw materials, which would imply that they possibly enjoyed an independent status during the Iron Age.

However, the above discussion still leaves unsolved the question why artisans seemingly flocked to Idalion, there creating an "Idalion Style" and rejected Tamassos as their place of business. For the limestone sculpture, an answer may be found in the geologic make-up of Cyprus. The limestone used for the crafting of sculpture originates from two sedimentary formations, the Lefkara and the Pakhna. While chalks from the first are generally more brittle and difficult to carve, Pakhna chalks could provide homogeneous blocks suitable for even carving large-scale sculptures. ${ }^{52}$ Within the framework of the presumed territories of ancient Idalion and Tamassos, the Pakhna formation emerges west and southwest of present-day Dhali (ancient Idalion), while the Lefkara formation can be observed over a large area to the southwest, south and southeast of this village. Both formations, however, are only scarcely present around present-day Politiko (ancient Tamassos). ${ }^{53}$ The ancient quarries, therefore, were concentrated within the territory of Idalion. ${ }^{54}$ The sculptors did already a great deal of the carving within the quarry, ${ }^{55}$ and we may assume that they finished the statues in workshops not far distant. All carving activities would, thus, be situated within the territory of Idalion. When the members of the upper stratum of Tamassos wished to commission large-scale limestone sculpture, they had to look beyond the borders of their own polity. As the Idalion quarries were the most proximate, it seems logical that Tamassos' upper class would mainly commission the workshops connected to these quarries. As a result, the Idalion carvers would develop a privileged bond with both the elites of Idalion and Tamassos and the "Idalion Style" would be visible in both polities.

Vrije Universiteit, Brussel

Justus-Liebig Universität, Giessen

51. Kozelj 1987, 21.

52. Kourou et al. 2002, 37-9.

53. Cf. The Geologic Map of Cyprus, 1995.

54. This can bc corroborated by the investigations of the Sydney Cyprus Survey Project, which did not find traces of quarrying within the explored part of the territory of Tamassos (Given, Knapp et al. 2003, 273).

55. This is attested by the discovery in quarries of unfinished sculptures, which were abandoned because of flaws in the stone (Palagia 1987, 81-2), e.g., the unfinished statues that were found in a quarry at Xylophagou-Mosphiloudia in the Larnaca district (Karageorghis 1969 , 494, fig. 130-133). 


\section{BIBLIOGRAPHY}

A LDRED (C.), 1988, Akhenaten King of Egypt, London.

Arafat (K.), Morgan (C.), 1989, "Pots and Potters in Athens and Corinth: A Review", OJA 8, 311-46.

BEAL (R.), 1988, "The GIS TUKUL-Institution in Second Millennium Hatti", Altorientalische Forschungen 15, 269-305.

BeCH GREgersen (M. L.), 1997, "Pylian Craftsmen: Payment in Kind/Rations or Land?", in Technè 1996, 397-405.

BEKKER-NIELSEN (T.), 2001, "The Ancient Road between Amathous and Tamassos", $R D A C, 247-54$.

BIEBER (A.M.), 1989, "Neutron Activation Analysis of Cypriote Pottery", in L.E. Stager, A.M. Walker (eds), American Expedition to Idalion, Cyprus 1973-1980, Chicago, 357-97.

BoARDMAN (J.), 1985, Greek Sculpture. The Classical Period, London.

BREHME (S.), BRÖNNER (M.), KARAGEORGHIS (V.), Platz-Horster (G.), Weisser (B.), 2001, Ancient Cypriote Art in Berlin. Antikensammlung, Museum für Vor-und Frühgeschichte, Münzkabinett, Nicosia.

BRONNER (M.), 1994, "Heads with Double Crowns", in Cypriote Stone Sculpture. 1993, 47-53.

BuchHolz (H.-G.), 2004, Der Werkstoff Holz und seine Nutzung im ostmediterranen Altertum, Weilheim/Oberbayern.

BUCHHOLZ (H.-G.), UNTIEDT (K1.), 1996, Tamassos. Ein antikes Königreich auf Zypern (SIMA-Pocket-Book 136), Jonsered.

CAubet (A.), 1991, "Recherche sur les ateliers de terre cuites de la partie occidentale de Chypre", in Cypriote Terracottas 1989, 109-14.

Caubet (A.), 1992, "The Terracotta Workshops of Idalion during the CyproArchaic Period", in P. Aström (ed.), Acta Cypria. Acts of an International Congress on Cypriote Archaeology Held in Göteborg on 22-24 August 1991 vol. 3, Jonsered, 128-51.
Caubet (A.), Yon (M.), 1989, "Ateliers de figurines à Kition", in V. Tatton-Brown (ed.), Cyprus and the East Mediterranean in the Iron Age. Proceedings of the Seventh British Museum Classical Colloquium, April 1988, London, 28-43.

Caubet (A.), Yon (M.), 1994, "Ateliers de sculpture de Kition: VI ${ }^{\mathrm{e}}-\mathrm{IV}^{\mathrm{e}}$ s. av. J.-C.", in Cypriote Stone Sculpture 1993, 97-105.

Cypriote Stone Sculpture 1993: Proceedings of the Second International Conference of Cypriote Studies BrusselsLiège, 17-19 May, 1993, Fr. Vandenabeele, R. Laffineur (eds), BrusselsLiège, 1994.

Cypriote Terracottas 1989 : Proceedings of the First International Conference of Cypriote Studies, Brussels-Liège-Amsterdam, 29 May-1 June, 1989, Fr. Vandenabeele, R. Laffineur (eds), Brussels-Liège, 1991.

EYRE (C.J.), 1987, "Work and the Organisation of Work in the New Kingdom", in M. A. Powell (ed.), Labor in the Ancient Near East, New Haven (Conn.), 166-221.

Fourrier (S.), 1999, Chypre et la Grèce de l'Est à l'époque archaïque (VII $-V I^{e}$ s. av. J.-C.). La plastique chypriote et les échanges en Méditerranée orientale, Ph.D. thesis, Université Lumière-Lyon 2.

FourRIER (S.), 2002, "Les territoires des royaumes chypriotes archaiques : une esquisse de géographie historique", $C C E C$ $32,135-46$.

GABER (P.), 1989, "Regional Styles in Cypriote Limestone Sculpture", in L.E. Stager, A.M. Walker (eds), American Expedition to Idalion, Cyprus 1973-1980, Chicago, 398-405.

GABER (P.), 1995, "The History of Idalion: A History of Interaction", in P. W. Wallace (ed.), Visitors, Immigrants, and Invaders in Cyprus, Albany, 32-9.

GABER (P.), 2000, "The Pottery from Idalion", in Praktika of the Third International Congress of Cypriot Studies, Nicosia, 471-84. 
Gaber-SaleTAN (P.), 1980, "The Limestone Sculpture from Kition", Medelhavsmuseet Bulletin 15, 41-9.

GABER-SAlETAN (P.), 1981, "The Limestone Sculpture from the Vouni Region", Medelhavsmuseet Bulletin 16, 39-46.

GABER-SALETAN (P.), 1986, Regional Styles in Cypriot Sculpture. The Sculpture from Idalion, New York-London.

GILlis (C.), 1997, "The Smith in the Late Bronze Age - State Employee, Independent Artisan, or Both?", in Technè 1996, 505-13.

GIVEN (M.), KNAPP (B.) et al., 2003, The Sydney Cyprus Survey Project. Social Approaches to Regional Archaeological Survey (Monumenta Archaelogica 21), Los Angeles.

GJerstad (G.), 1948, The Swedish Cyprus Expedition IV:2. The Cypro-Geometric, Cypro-Archaic and Cypro-Classical Periods, Stockholm.

Gjerstad (G.), 1960, "Pottery Types CyproGeometric to Cypro-Classical", OpAth 3, 105-22.

Hermary (A.), 1991, "Les débuts de la grande plastique chypriotc en terre cuite", in Cypriote Terracottas 1989, 139-47.

HERMARY (A.), 1996, "Les sculptures en pierre", in D. Buitron-Oliver et al., The Sanctuary of Apollo Hylates at Kourion: Excavations in the Archaic Precinct (SIMA 109), Jonsered, 139-49.

HOGARTH (D. G.), 1898-9, "Excavations at Naukratis A. Site and Buildings", BSA 5, 26-46.

IAcovou (M.), 2002, "From Ten to Naught. Formation, Consolidation and Abolition of Cyprus' Iron Age Polities", CCEC 32, 73-87.

Jones (R. E.), Catling (H.), 1986, "Cyprus, 2500-500 BC; the Aegean and the Near East, 1500-1050 BC", in R. E. Jones, Greek and Cypriot Pottery. A Review of Scientific Studies, Athens, 523-625.

KARAGEORGHIS (J.), 1999, The Coroplastic Art of Ancient Cyprus V. The CyproArchaic Period. Small Female Figurines B. Figurines moulées, Nicosia.
KARAgEORghis (V.), 1969, "Chronique des fouilles et découvertes archéologiques à Chypre en 1968", $B C H$ 93, 431-569.

Karageorghis (V.), 1991, "The Coroplastic Art of Cyprus: An Introduction", in Cypriote Terracottas 1989, 9-16.

KaRAGEORghis (V.), 1993, The Coroplastic Art of Ancient Cyprus III. The CyproArchaic Period. Large and Medium Size Sculpture, Nicosia.

KARAGEORGHIS (V.), 2003, Cypriote Antiquities in the Royal Ontario Museum, Nicosia.

Kourou (N.), Karageorghis (V.), MaNiatis (Y.), Polikreti (K.), Bassiakos (Y.), XENOPHONTOS (C.), 2002, Limestone Statuettes of Cypriote Type Found in the Aegean. Provenance Studies, Nicosia.

KozELJ (T.), 1987, "De marmergroeven in de oudheid", in D. Vanhove (ed.), Marmer in Hellas. Van steengroeve tot kunstwerk. Ghent, 20-33.

MaIer (F. G.), 1989, "Priest Kings in Cyprus", in E. Peltenburg (ed.), Early Society in Cyprus, Edinburgh, 376-91.

M ARK (I. S.), 1995, "The Lure of Philosophy: Craft and Higher Learning in Ancient Greece", in W. G. Moon (ed.), Polykleitos, the Doryphoros and Tradition, Madison (Wisconsin), 25-37.

MASSON (O.), 1977, "Vase chypriote inscrit pour un 'fabricant d'arc' ", $R D A C, 154-6$.

MAsson (O.), 1983, Les inscriptions chypriotes syllabiques ${ }^{2}$, Paris.

MatтhÄUS (H.), 1985, Metallgefäße und Gefäßuntersätze der Bronzezeit, der geometrischen und archaischen Periode auf Cypern (Prähistorische Bronzefunde II:8), Munich.

MITFORD (T. B.), 1971, The Inscriptions of Kourion, Philadelphia.

Mitford (T. B), 1980, The Nymphaeum of Kafizin. The Inscribed Pottery (Kadmos Suppl. 2), Berlin-New York.

MoNloup (Th.), 1984, Les figurines de terre cuite de tradition archaiqque (Salamine de Chypre XII), Paris.

MONLOUP (Th.), 1994, Les terres cuites classiques. Un sanctuaire de la grande déesse (Salamine de Chypre XIV), Paris. 
Morgan (C.), 1991, "Ethnicity and Early Greek States: Historical and Material Perspectives", Proceedings of the Cambridge Philological Society 37, 131-63.

Morgan (C.), Whitelaw (T.), 1991, "Pots and Politics: Ceramic Evidence for the Rise of the Argive State", AJA 95, 79-108.

NIJBOER (A.J.), 1997, "The Role of Craftsmen in the Urbanization Process of Central Italy (8th to 6th Centuries BC", in H. Damgaard Andersen et al. (eds), Urbanization in the Mediterranean in the 9th to 6th Centuries BC (Acta Hyperborea 7), Copenhagen, 383-406.

NYS (K.), 2000, Cypriote Pottery with Zoomorphic and Anthropomorphic Plastic Decoration. From the End of the Bronze Age to the Hellenistic Period, Unpublished Ph.D. thesis, Vrije Universiteit Brussel. (revised version forthcoming as $M a n$, Bulls and Other Beasts (SIMA 131), Sävedalen)

NyS (K.), forthcoming. "The Iron Age Vases with Plastic Decoration from Tamassos", in H.-G. Buchholz et al., Tamassos.

Palagia (O.), 1987, "Technieken van de Griekse marmersculptuur", in D. Vanhove (ed.), Marmer in Hellas. Van steengroeve tot kunstwerk, Ghent, 76-89.

PHILIPP (H.), 1990, "Handwerker und bildende Künstler in der griechischen Gesellschaft (Kat. 9-18). Von homerischer Zeit bis zum Ende des 5. Jahrhunderts v. Chr.", in Polyklet. Der Bildhauer der griechischen Klassik, Mainz am Rhein, 79-110.

Postgate (J. N.), 1987, “Employer, Employee and Employment in the NeoAssyrian Empire", in M. A. Powell (ed.), Labor in the Ancient Near East, New Haven (Conn.), 257-70.

PRYCE (F. N.), 1931, Catalogue of Sculpture in the Department of Greek and Roman Antiquities of the British Museum I.2. Cypriote and Etruscan, London.

REYES (A. T.), 1992, "The Anthropomorphic Bronze Statuettes of Archaic Idalion, Cyprus", BSA 87, 243-57.

Reyes (A. T.), 1994, Archaic Cyprus. A Study of the Textual and Archaeological Evidence, Oxford.
REYES (A. T.), 2001, The Stamp-Seals of Ancient Cyprus, Oxford.

RuPP (D. W.), 1989, "Puttin' on the Ritz: Manifestations of High Status in Iron Age Cyprus", in E. Peltenburg (ed.), Early Society in Cyprus, Edinburgh, 336-62.

SENFF (R.), 1993, Das Apollonheiligtum von Idalion (SIMA 94), Jonsered.

TANNER (J.), 1999, "Culture, Social Structure and the Status of Visual Artists in Classical Greece", Proceedings of the Cambridge Philological Society 45, 136-75.

Technè 1996: Technè. Craftsmen, Craftswomen and Craftsmanship in the Aegean Bronze Age. Proceedings of the 6th International Aegean Conference/ 6e Rencontre égéenne internationale, Philadelphia, Temple University, 18-21 April 1996 (Aegaeum 16), R. Laffineur, P.P. Betancourt (eds), Liège, 1997.

VANDENABEELE (Fr.), 1998, Figurines on Cypriote Jugs Holding an Oinochoe (SIMA 120), Jonsered.

VIVIERS (D.), 1995, "Les ateliers de sculpteurs en Attique : des styles pour une cité", in A. Verbanck-Piérard, D. Viviers (eds), Culture et Cité. L'avènement d'Athènes à l'époque archaïque. Actes du Colloque international, Université libre de Bruxelles, 25-27 avril 1991, l'Institut des Hautes Etudes de Belgique et la Fondation Archéologique de l'U.L.B., Bruxelles, 21123.

WINTER (N. A.), 1991, "Terracotta Figurines from Kourion: The Workshops", in Cypriote Terracottas 1989, 221-24.

WINTER (N. A.), 1991, "The Terracottas", in D. Buitron-Oliver et al., The Sanctuary of Apollo Hylates at Kourion: Excavations in the Archaic Precinct (SIMA 109), Jonsered, 89-137.

WRIEDT SøRENSEN (L.), 1994, "The Divine Image?", Cypriote Stone Sculpture 1993, 79-89.

YoN (M.), 1974, Un dépôt de sculptures archaiques (Salamine de Chypre V), Paris.

Yon (M.), CAUbET (A.), 1988, "Un culte populaire de la Grande Déesse à Lapithos", $R D A C, 1-16$. 